\title{
Who Gives Foreign Aid to Whom and Why?
}

\section{Citation}

Alesina, Alberto, and David Dollar. 2000. Who gives foreign aid to whom and why?. Journal of Economic Growth 5(1): 33-63.

\section{Published Version}

doi:10.1023/A:1009874203400

\section{Permanent link}

http://nrs.harvard.edu/urn-3:HUL.InstRepos:4553020

\section{Terms of Use}

This article was downloaded from Harvard University's DASH repository, and is made available under the terms and conditions applicable to Other Posted Material, as set forth at http:// nrs.harvard.edu/urn-3:HUL.InstRepos:dash.current.terms-of-use\#LAA

\section{Share Your Story}

The Harvard community has made this article openly available.

Please share how this access benefits you. Submit a story.

Accessibility 


\section{NBER WORKING PAPER SERIES}

\section{WHO GIVES FOREIGN AID \\ TO WHOM AND WHY?}

\section{Alberto Alesina \\ David Dollar}

Working Paper 6612

http:/www.nber.org/papers/w6612

\section{NATIONAL BUREAU OF ECONOMIC RESEARCH \\ 1050 Massachusetts Avenue \\ Cambridge, MA 02138 \\ June 1998}

We thank Robert Barro, William Easterly, Lisa Martin, and Lant Pritchett for useful suggestions, Romain Wacziarg for sharing some data, and Guiseppe larossi for outstanding research assistance. Alesina is grateful to the NSF for financial support through the NBER. Any opinions expressed are those of the author and not those of the National Bureau of Economic Rescarch.

(C) 1998 by Alberto Alesina and David Dollar. All rights reserved. Short sections of text, not to exceed two paragraphs, may be quoted without explicit permission provided that full credit, including 0 notice, is given to the source. 
Who Gives Foreign Aid to Whom and Why?

Alberto Alesina and David Dollar

NBER Working Paper No. 6612

June 1998

\title{
ABSTRACT
}

This paper studies the pattern of allocation of foreign aid from various donors to receiving countries: We find considerable evidence that the direction of foreign aid is dictated by political and strategic considerations, much more than by the economic needs and policy performance of the recipients. Colonial past and political alliances are the major determinants of foreign aid. At the margin, however, countries that democratize receive more aid, ceteris paribus. While foreign aid flows respond more to political variables, foreign direct investments are more sensitive to economic incentives, particularly "good policies" and protection of property rights in the receiving countries. We also uncover significant differences in the behavior of different donors.

\author{
Alberto Alesina \\ Department of Economics \\ Harvard University \\ Cambridge, MA 02138 \\ and NBER \\ aalesina@harvard.edu
}

David Dollar

1818 H Street NW

Washington, DC 20433 


\section{Introduction}

The benefits of foreign aid have recently been under severe scrutiny. Several observers argue that a very large portion of foreign aid flowing from developed to developing countries is wasted and only increases unproductive public consumption. Poor institutional development, corruption, inefficiencies and bureaucratic failures in the developing countries are often cited as reasons for these results.

In this paper we ask whether the pattem of aid giving in the advanced industrial countries aiso contributed to this failure. That is, do developed countries respond to the economically correct incentives in giving foreign aid? Or, instead, is the pattern of aid flows dictated by political and strategic considerations which have little to do with rewarding good policies and helping the more efficient and less corrupt regimes in developing countries?

We find considerable evidence that the pattern of aid giving is dictated by political and strategic considerations. An inefficient, economically closed, mismanaged non-democratic former colony politically friendly to its former colonizer, receives more foreign aid than another country with similar level of poverty, a superior policy stance, but without a past as a colony. We also find significant differences between donors. Certain donors (notably the Nordic countries) seem to respond more to the "correct" incentives, namely income levels, good institutions of the receiving countries, and openness. Other countries (notably France) give to former colonies tied by political 
alliances, without much regard to other factors, including poverty levels or choice of politico-economic regines. The United States's pattem of aid giving is vastiy influenced by that country's interest in the Middle East.

A. related point concerns whether foreign aid has been used to foster the process of democratization or not. We find strong evidence that countries which have democratized have received a "surge" in foreign aid, immediately afterwards. The typical democratizing country gets a $50 \%$ increase in aid. Our results on cross sections and time series can be summarized as follows. Cross country differences are largely explained by "political" factors, such as colonial links, alliances, strategic interests, etc. However, at the margin, changes in aid flows over time in a country tend to reward "good" policies, notably democratization and openness.

While foreign aid responds to "political incentives," foreign direct investments are more sensitive to economic conditions in the receiving countries. Interestingly, while foreign aid responds more directly to "political" openness (democratization), FDI responds more to "economic" openness (improvement in policy management, trade liberalization, better protection of property rights).

This paper is organized as follows. Section 2 briefly summarizes the most important results of the available literature on foreign aid. Section 3 describes our data set. Section 4 provide evidence on bilateral aggregate aid flows. Section 5 describes results divided by donor countries. Section 6 studies whether foreign aid rewards or 
foster the democratization process, and the adoption of more "open" policies. The last section concludes.

\section{Literature review}

The literature on foreign aid can be divided in two parts. One studies the effects of foreign aid on the receiving countries; the other investigates the determinants of foreign aid, namely which donor gives to which recipient and why.

On the first point, Jepma (1997) presents a broad survey of the literature from the seventies onward. His conclusions are that, for the most part, foreign aid crowds out private saving, supports public consumption, and has no significant positive impact on the recipients' macroeconomic policies and growth. This survey, however, correctly points out several methodological weaknesses of the early literature. A key issue is the "chicken and the egg" problem. If one observes a correlation between aid, poverty and bad policies, does this mean that foreign aid is misdirected, or that aid is used to relieve the sufferings of the populations of countries with economic problems?

A more recent literature inspired by the renewed interest in cross country growth empirics, has addressed this issue. In a series of papers Boone $(1994,1996)$ finds that foreign aid has absolutely no effects on investment and growth in a large sample of developing countries, after controlling for the endogeneity of aid flows. Burnside and Dollar (1997) study the interactions among choice of macroeconomic policies, aid and 
growth. They find that aid is beneficial to countries that adopt appropriate and stable policies, and otherwise it is wasted. However, they find no evidence that foreign aid encourages the adoption of "good" macroeconomic policies. They also suggest that donors" "strategic" interests are more important than the quality of the policies of the receiving countries as an explanation of aid flows, an issue which is particularly connected with the present study.

The second question, namely the explanation of aid flows, is our main interest here. Lumsdaine (1993) emphasizes several determinants of the direction of aid which we also consider in the present paper, such as colonial history, the democratic status of the recipients, income levels, etc. However, he presents only simple correlations, so that he cannot study interactions and the relative magnitude of the effects of different explanatory variables. Lumsdaine emphasizes the "moral vision" (which is also the title of his book) that, according to him, underlies foreign aid giving.

This "idealistic" view sharply contrasts with a voluminous literature that has argued that strategic foreign policy concerns explain the pattern of foreign aid. For 
instance, this point is made by Maizels and Nissanke (1984). Unfortunately, the measurement of what a "strategic interest" is varies from study to study and is occasionally tautological. As a result, the literature is rather fragmented, with one study emphasizing this or that variable and with relatively little attempt at confronting the impact of different variables and their interactions. In other words, while there is some general agreement about what matters for aid giving, namely poverty of the recipients, strategic interests, colonial history, trade, political institutions of the recipients, etc., there is virtually no solid evidence on the relative importance of different variables. The complexity of the determinants of aid flows is well documented by a recent study by Schraeder, Hook and Taylor (1998). They restrict their attention to Africa and easily reject an altruistic vision of donors' motivation. They also highlight interesting differences between donors, related to their position in the world order, strategic interest and relationship with former colonies. Finally, most authors find that the determinants of bilateral and multilateral aid are quite different and one cannot explain the two together ${ }^{3}$ In what follow we focus on bilateral aid.

${ }^{1}$ This paper also includes a good survey of the literature on this point, up to the mid-eighties.

${ }^{2}$ For example Trumbull and Wall (1994) find that a measure of infant mortality in their specification is stronger than income per capita of the recipients country in explaining bilateral aid, a result which does not survive in our results below.

${ }^{3}$ See for instance Maizels and Nissanke (1984) on the difference between bilateral and multilateral aid. Frey and Schneider (1986) amongst others study the deterninants of multilateral aid. 


\section{Data}

We use the data on bilateral aid flows reported by the Development Assistance Commitee of the OECD. We have converted the flows into constant 1985 dollars and for much of our analysis average these for fve year periods beginning with 1970.74 and ending with 1990-94. While we cover a wide range of donors, it should be noted that $70 \%$ of the total is accounted for by four countries: U.S., Japan, France, and Germany

(Figure 3.1) Our objective is to explain the behavior of bilateral donors - in the aggregate and individually -- on the basis of recipients' poverty, the quality of their institutions and policy, and variables capturing the strategic interests of donors.

Specifically, we relate the flows to the following variables:

- trade openness: a zero-one index developed by Sachs and Wamer (1995)

- democracy: an index from Freedom House

- civil Lberties: an index from Freedom House (correlated about 9 with the above)

- colonial status: the number of years in the 20 th century that a country was a colony

- direct foreign investment: FDI flow relative to GNP

- initial income: real (PPP) per capita income at the beginning of a period

- population.

A more detailed description of the data used and sources is in the Appendix. 
The correlation of bilateral aid per capita with these variables is shown in Table

3.1. The strongest relationship is with population (small countries get more per capita) and with colonial status. There is a slight positive relationship between initial income and aid, somewhat surprising in that presumably poverty reduction is an important ain. There is also a modest positive association of aid with openness and with democracy. Note that the Sachs-Warner index is sometimes criticized for measuring something which is much broader than trade openness strictly defined. This problem does not concern us particularly. In fact, we are not particularly interested in "trade openness" per se strictly defined. For us an index of "open policies" like the Sachs-Wamer one is, in fact, even more appropriate.

The influence of colonial past varies enormously by donor, reflecting their different histories as colonial powers. For individual donors, the share of aid going to countries that were their colonies in the 20 th century varies from $99.6 \%$ (Portugal) to zero for countries such as Canada and Sweden that had no colonies (Table 3.2).

To get a more objective measure of "donor strategic interests" than has been previously used in the literature, we tumed to the records on UN voting patterns For each donor-recipient pair, we calculated the correlation of their voting records in the general assembly and used this as an index of each donor country's friends. There was some risk that this would not be a fruitful approach for two reasons. First, it is possible that the UN votes are mostly meaningless so that the patterns are not important.

Second, even if the patterns of voting in the UN are important, it may be that the voting behavior of the big donors (all members of the G-7) is so similar that it would be hard to 
distinguish the friends of the US, from, say, Japan's friends, if "friendship" is judged by UN voting patterns. Tt tumed out that the latter concern was not warranted. USFriend is correlated only .37 with Japanfriend, .53 with FrenchFriend, and .72 with UKFriend (Table 3.3). Thus, there appear to be distinguishable voting blocs in the UN.

Concening the first objection, one may argue that even though many UN votes may not be very important, they may still be an accurate signal of alliances and common interest. in other words, even though UN votes may be not that important, they may be correlated very strongly with important strategic interests.

\section{Aggregate results}

We begin with several regressions on aggregate bilateral aid flows, summarized in Table 4.1. Column (1) reports our "base" specification. The dependent variable is the log of total bilateral aid. Income per capita enters both linearly and quadratically. The coefficients on initial income imply that aid is insensitive to the level of income among low-income countries, but that it drops off sharply as countries move to middle-income status (other things equal). Population also enters both linearly and quadratically. The elasticity of aid with respect to population is about [0.60] evaluated at the mean; that is, small countries receive more aid per capita.

The next two variables measure democratic institutions and open trade policies. More open and more democratic countries receive more aid. Countries with a colonial 
past also are favored. As for UN voting patterns, friends of Japan receive more aid, while US friends do not. The latter result at first glance is surprising. Note, however, that US aid is vastly concentrated to the Middle East: one-third of the U.S. aid in our data set went to Egypt and Israel. This is why the indicator variables for Egypt and Israel are very large and highly significant. We have also added variables "UN Friend" for all the other major donors, in addition to the US and Japan. All these variables are insignificant and do not affect the results in any way. All the results on the other explanatory variables are unaffected if we exclude the variable "Japan UN friend." When we omit the variables for Egypt and Israel [in column (4)], the coefficient on USFriend becomes statistically significant. This result suggests that issues of the Middle East are important determinants of votes in the UN.

The values of the coefficients are very instructive. Ceteris paribus a country that is relatively open ( 1 standard deviation above the mean) receives 17 per cent more aid (Figure 4.1). A country that is relativeiy democratic (1 standard deviation above the mean) receives 36 per cent more aid; a country that has a relatively long colonial past (1 standard deviation above the mean) receives 72 per cent more aid; a country that voted relatively often with Japan in the UN receives 177 per cent more aid. Finally Egypt and Israel receive much more aid than other countries with similar characteristics. Egypt receives 481 per cent more and the value for Israel is basically off the scale. This is because Israel is a relatively rich country with no colonial past. Thus according to the regression this country should receive virtually no aid; instead Israel receives about [\$400] per capita. 
These results suggest that political and strategic considerations are more important than recipient's policy or political institutions. Another way to look at the relative importance of different variables is to introduce them into the regression sequentially. Population plus time dummies alone can explain $17 \%$ of the variation in bilateral aid flows. Adding income per capita, democracy, and openness increases the R-squared by 0.13 to 0.30 . Alternatively, adding the UN Friends variables, colonial past, and dummies for Israel and Egypt increases the R-squared by nearly twice as much - 400.37 . In this sense we can say that the political-strategic variables have more explanatory power thar the measures of poverty, democracy, and policy.

In column (2) of Table 4.1 we drop the communist countries from the sample. The point of this exercise is to check whether the result on "democracy" is driven by the fact that communist countries did not receive much aid from westem donors before the collapse of the Berlin wall. The coefecient on democracy falls in value but remains well above standard levels of statistical significance. 
In column (3) we add a measure of civil liberty, and in column (5) a measure of rule of law. ${ }^{4}$ Both variables are insignificant, while the democracy variable still is. Therefore, these regressions suggest that bilateral aid is particularly influenced by democratic institutions strictly defined, rather than a broader definition of civil rights and enforcement of the law. The reason why this is interesting is that the results on this point are quite different in the case of foreign direct investment [columns ( 6 ) and (7)]. Foreign direct investment responds positively to rule of law, but is insensitive to democratic institutions. Thus, private capital flows are influenced by the enforceability of contracts, rule of law and "economic liberty"; they are not sensitive to political democracy per se. In contrast, public funds respond more to the presence of democratic institutions. More generally the regressions for FDI show important differences with respect to the bilateral aid regressions: in particular, openness (an indicator of "good" economic policy) is more important for FDI than for bilateral aid. Many of the "strategic variables" lose significance in the FDI regressions. For instance, colonial past is insignificant, the indicator variable for Israel is insignificant, and the one for Egypt much lower. The UN friend is only marginally significant. This is reasonable, since private investors should respond primarily to economic incentives, not political ones. Another important point about private capital flows is that, after controlling for rule of law and openness, they disproportionately go to richer countries, probably because the latter have larger markets.

\footnotetext{
Because of data availability on the rule of law variable we have to drop the seventies from our sample.

s We considered the possibility that FDI belongs in the bilateral aid equation and/or that aid belongs in the FDI equation. We can use the strategic interest variables and democracy as instruments for aid since FDI is not a function of these; similarly, we can use rule of law and similar variables as instruments
} 
Our results are robust to several sensitivity checks. For example we tried other indicators of poverty, in addition to initial income. Infant mortality is marginally significant, without affecting any other coefficient, including initial income per capita. ${ }^{6}$

Figures 4.2 and 4.3 ilustrate well the relative importance of being a colony yersus other characteristics of the receiving countries. In these figures "colonial past" Tefers to any country which has been a colony of a donor in the 20th century; "more democratic" is a country with a value of the Gastil index below 5; "less democratic" are the others. "Open" is a country with the index value of one; "closed" are the others. Figure 4.2 shows that "colonial past" is much more important than "democracy" as a deteminant of foreign aid. More democratic countries get a bit more than less democratic ones, but these differences are trivial compared with the differences between colonies and non-colonies. A non-democratic former colony receives almost 25 dollars per capita, a democratic non-colony about 14 dollars per capita. Figure 4.3 shows that colonial status is also more important than the adoption of "open" economic policies. A "closed" fomer colony gets more than fifty per cent more than an "open" non-colony: aimost 23 dollars per capita versus 14 dollars per capita. Also, for both colonies and non-colonies, "open" countries get more than "closed" ones, but the differences between the two is much less than the difference between colonies and non colonies.

for FDI since aid is not a function of these. In 2SLS regressions we found no evidence that aid depends on FDI or that FDI depends on aid. The flows appear to be quite independent.

${ }^{6}$ On this point our results (available on request) differ from Trumbull and Wall (1994). 


\section{Donor by Donor Results}

While it is useful to model the aggregate behavior of bilateral conors, there are interesting differences among donors that are revealed when aid allocation equations are estimated donor by donor. Table 5.1 displays our results. (There was enough similarity in the aid allocations of the Nordic countries - Denmark, Finland, Norway, and Sweden - that it made sense to aggregate these in this section.) The main findings can be summarized as follows:

a) Colonial past:

We include two colonial variables: One is the log of the number of years in the 20 th century in which a recipient was a colony of the donor; the second colony variable captures the number of years in which the recipient was a colony of another donor.

As expected, in virtually all the regressions the "own colony" variable is highly significant, in some cases with t-statistics above 15 . The coefficients can be interpreted as elasticities. So, for example, doubling the length of time as a colony of France would result in a $100 \%$ increase in aid. In the case of Japan, it would result in $165 \%$ increase. The other donors" "colony variable" checks whether donors compensate by discriminating against other donors' fomer colonies. The answer is generally no, since this variable in the regressions generally has a nonsignificant coefficient. In fact, in the 
few cases in which the coefficient is significant it has the "wrong" sign, indicating that donors give more rather than less to other donors' colonies. These results explain why the colony variable was so important in the aggregate regressions presented in the previous section (Table 4.1).

Table 5.1 also reports the share of non-zero observations for each donor. ${ }^{7}$ For bilateral aid overall, oniy $3 \%$ of the observations in the data-set were zeroes, and for this reason we chose OLS for the estimation. For most of the major donors the share of zeroes is below 10\%. This information is in itself quite interesting, as it indicates that donors like to be involved everywhere, even if only to a minor extent. The issue is alsc inportant from the point of view of estimation, because OLS is not the preferred approach if there are a large number of zero observations. Given the small number of zeroes for major donors, we prefer to remain with OLS for all of the regressions. If our study were focusing to a large extent on the small donors, such as Portugal or Australia, then the preferred approach would be to use probit to estirnate the likelihood that a developing country receives aid and then tobit to estimate the response of the aid flow to the variables that we have in our regressions. Under certain conditions, the tobit estimates will be close to the OLS estimates multiplied by 1 divided by the proportion of non-zero observations (Greene, 1993). For most of the countries in Table 5.1 this correction would be minor. In the case of Portugal, however, the correction factor

\footnotetext{
${ }^{7}$ In order not to lose the zero observations when making the logrithmic transformation, we added $[\$ 1,000]$ to each observation.
} 
would be about 8 , indicating that the tobit estimate of the responsiveness of Portuguese aid to colonial past is far higher than the OLS estimated elasticity of 0.49 .

Another important point about the colony variable is that its overall impact on aid allocations depends on the elasticity reported in Table 5.1 as well as the extent of the donor's experience as a colonizer. Japan has a large estimated elasticity of aid with respect to colonial past, but it did not have many colonies. Referring back to Table 3.2, only $6.3 \%$ of Japanese aid has gone to former colonies. France and the U.K., on the other hand, have smaller elasticities with respect to colonial past, but because of their greater number of former colonies they have given $57 \%$ and $78 \%$, respectively, of their total aid to their former colonies.

\section{b) UN Friend}

The UN friend variable is generally significant and, in particular is significant for all the major players in international relations included in these regressions, namely the U.S., Japan, France, Germany, and the UK. In no regression does this variable have the incorrect sign. Note that the USFriend variable is significant in the US regression even though the indicator variables for Egypt and Israel are included. The coefficients can be interpreted as follows: the average developing country voted together with France $64 \%$ of the time. One standard deviation above the mean -- in terms of political friendliness - would be a country voting $73 \%$ of the time with France. That shift is associated with 
an $82 \%$ increase in French aid. F one standard deviation increase in voting correlation is associated with a $65 \%$ increase in U.S. aid, and a $200 \%$ increase in Japanese aid.

The results on UN friends as a proxy for strategic allies can be interpreted in two ways. One is that aid is used to "buy" political support in the UN, namely aid buys UN votes in favor of the donor. The second one is that UN votes are simply an indication and manifestation of the political alliances between countries. While either interpretation is consistent with our resuits, on a priori ground we favor the second one. In fact, many UN votes are fairly irrelevant, per se, given the relative lack of decisional power of this organization. Thus, while the donors may not give aid to "buy" fairly unimportant votes in the UN, the same votes nevertheless could be a good indicator of existing alliance blocks.

c) Egypt and Israel.

For well known reasons having to do with the conflict in the Middle East, these two countries have received in the last decades much political and economic support from westem powers. Not surprisingly, the indicator variables for these two countries are statistically very significant and are very large for the U.S. regression. Israel also has gotten large support from Germany, and to a lesser extent the Netherlands. Egypt gets unusually large support from most of the donors: France, Japan, Germany, Australia, Austria, the Netherlands, Canada, and the Nordics. 
d) Income of the recipient

As in table 4.1 we have used income both linearly and quadratically. In order to make the interpretation more transparent we simply report the elasticity of aid with respect to income calculated at the mean of income

Most donors give more to poorer countries, ceteris paribus. However, there is quite a large variation among donors in the relationship of aid to poverty (Figure 5.1). The highest elasticity is for Nordic countries, followed by the U.S. (and the Netherlands, not shown in the figure). Of the major donors the countries with the lowest elasticity to income of the recipients are France and $\mathrm{Japan}^{8}$. In the case of France, there is simply not much relationship between aid and recipients' income. In the case of Japan, aid increases with income up to a level of about \$1,500 per capita GDP (PPP), and then declines. Note that since we are controlling for colonial status, these different elasticities across donors cannot be explained by the fact that different donors have poorer or richer former colonies.

Two small donors, Belgium and Portugal, have even smaller (in absolute value) elasticities. Another small donor, Austria, has a positive elasticity. 
e) Openness.

The variable "openness" has a positive coefficient with a t-statistic above 3 for the U.S., U.K., France, Japan, Australia, and the Nordics. For most of these donors the coefficient is around 1 , indicating that open economies get about twice as much assistance as closed ones ceteris paribus. This indicates that donors are making an effort to reward good economic policy. This effort is undermined, however, by other objectives. In general, the colony variable and the UN Friends variables are virtually uncorrelated with openness. Thus, the allocation of aid to former colonies and to strategic allies tends to make it indiscriminate with respect to recipients' economic policy.

f) Democracy

Democracy is an area in which there are clear differences among major donors. The strongest positive response to democratic institutions is for the U.S., the Dutch, the Nordics, and Canada. Of the major donors, France is the one that seems to pay no attention to the democracy of the receiving country, while Germany and Japan put a small weight on this factor. Once again these results are obtained holding "colonial past" constant. Therefore they can not be explained only by the fact that different colonizers have more or less democratic regimes in former colonies. 
In summary, one notes several interesting differences among donors. Nordic countries target their assistance to the poorest countries, and within that appear to reward good policies and political institutions of the receiving countries. U.S. behavior is similar to the Nordics at the margin, but has the additional feature of being allocated in favor of UN friends and Middle East allies. On the opposite extreme among majot donors are France and Japan, donors which seem to care mostly about their own former colonies and UN votes, do not particularly reward good policies or institutions, and are less reactive than other donors to the income level of the recipients. ${ }^{9}$

\section{Does aid foster and reward democratization and "open" policies?}

While we have organized the data into a panel, the results presented so far depend largely on cross-sectional variation. Some of the inportant variables, such as colonial past, do not change at all over the 1970-94 period, while others such as population and per capita income change slowly. Two variables in which we have a particular interest in the time series variation are democracy and openness. The question we address in this section is whether a particular country that democratizes or liberalizes trade can expect to see an increase in aid. We also want to look at the time patterns of aid, on the one hand, and democratization and trade liberalization, on the other. Do shocks to aid follow shocks to democracy and openness as a rule, or do they lead them?

\footnotetext{
9 In their analysis of aid to Africa, Schraeder, Hook and Taylor (1998) find results broadly consistent (when applicable) to these.
} 
To address these questions we have used the annul data and organized them in several ways. First, we isolate the cases in which, over a three-year period, there is a change of at least one standard deviation (1.9 points) in the Freedom House index of democracy. This approach gives us 59 "democratization" episodes (with some countries having more than one episode) and 42 episodes in which the democracy measure goes down by at least 1.9 points in a three-year period (Table 6.1). For the democratization episodes, the average aid was $\$ 27$ per capita in the three years prior to the onset of democratization, $\$ 41$ during the episode (a $50 \%$ increase), and $\$ 35$ in the three years afterwards. In about $75 \%$ of the episodes the amount of aid went up during democratization. Thus, there is a very clear tendency for bilateral donors to reward countries that democratize. There is an asymmetry in donors ${ }^{7}$ reactions to decreases in democracy: they tend to reduce aid but not by as large a percentage as they increase aid in response to a positive change in democracy.

In Figure 6.1 we pick out a number of the cases in which there were large changes in the democracy index. In the Philippines the overthrow of the Marcos regime was followed by a large increase in aid. The cases of Bolivia and Peru are similar. Experiences in Africa are more varied. In Zambia there was a steady increase in assistance to the same authoritarian regime from 1970 through the mid-1980s, and then a further modest increase with the recent move toward democracy. In Senegal, on the other hand, there was a much closer relationship between democracy and aid. 
In Table 6.2 we carry out an analogous exercise for trade liberalization episodes, as defined by Sachs and Warner (1995). There is a similar, though weaker, finding. In about $75 \%$ of trade liberalizations, aid receipts rise. The average receipt goes from $\$ 29$ per capita pre-reform to $\$ 36$ (about a 25\% increase) during reform. In the three years after reform, however, the average was $\$ 28$ per capita, about the same as pre-reform. In the 13 cases in which the change goes from open to closed, there is no reaction of the amount of aid.

We get similar results with fixed effects panel regressions on the annual data (Table 6.3). The coefficients on democracy and openness are remarkably similar to those in regression 2 of Table 4.1. The table includes an interactive term between democracy and openness which it can be seen has no significance (no extra benefits for the combination of political and economic reform). We experimented with different lags, and generally found that the response of bilateral donors to democratization or liberalization is quite rapid.

Thus, shocks to democracy and to a lesser extent shocks to openness are good predictors of shocks to aid. We also considered the converse question, whether shocks to aid lead or predict democratization or trade liberalization. Using the same methodology as above, we found about 100 cases of large increases in aid and a similar number of large decreases. Twelve of the large increases were followed by significant democratization, and 16 of the large decreases were followed by democratization. We found similar results for trade liberalization: there is no tendency for shocks to aid to be 
followed by changes in democracy or openness. Thus, the time series evidence is that aid flows respond to democratization or liberaization episodes (and may help consolidate these). It is not typically the case that large changes in aid (either up or down) precede political or economic reform.

\section{Conclusions}

Most observers agree that foreign aid has at best been, at best, only partially successful at promoting growth and reducing poverty. One reason is the poor performance of the bureaucracies of the receiving countries. The other reason (documented in this paper) is the pattern of the flows of foreign aid. The allocation of bilateral aid across recipient countries provides evidence as to why it is not more effective at promoting growth and poverty reduction. Factors such as colonial past and voting patterns in the United Nations explain more of the distribution of aid than the political institutions or economic policy of recipients. Most striking here is that a nondemocratic former colony gets about twice as much aid as a democratic non-colony. A similar result holds for former colonies that are closed to trade versus open noncolonies.

From the point of view of efficient aid, each of the tbig three" donors -- U.S., Japan, and France -- has a different distortion: the U.S. has targeted about one-third of its total assistance to Egypt and Israel; France has given overwhelmingly to its former colonies; and Japan's aid is highly correlated with UN voting patterns (countries that 
vote in tandem with Japan receive more assistance). These countries' aid allocations may be very effective at promoting strategic interests, but the result is that bilateral aid has only a weak association with poverty, democracy, and good policy.

When we estimate equations for individual donors, we find striking differences in their allocations. After controlling for its special interest in Egypt and Israel, U.S. aid is targeted to poverty, democracy, and openness. The Nordic countries have a similar pattern except that they do not have the same sharp focus on the Middle East. Japanese and French assistance, on the other hand, has littie relationship to poverty or denocracy even after controlling for their strategic interests in fomer colonies and UN friends.

We also looked at the time series relationships between aid, on the one hand, and democracy and openness, on the other. There is a very clear trend for democratizers to get a substantial increase in assistance ( 50 percent on average), and a weaker trend for trade liberalizers to be boosted (a temporary 25 percent increase on average). In terms of the incentives implicit in aid allocations, this time series dimension is what is important: it reveals what a particular country can expect as it reforms political institutions and economic policy.

Finally, we estimated an equation for the flow of direct foreign investment, which provides a useful reference point for aid allocations. We found no mutual dependence of private flows and bilateral aid. Private flows respond to the rule of law and good economic policy, and are indifferent to democracy or the strategic considerations that 
play such an important role in aid allocations. Ceteris paribus, private flows go to higher income developing countries, probably because they have larger markets. This last finding is important, because it reveals that low-income countries cannot expect much in the way of private flows even if they have good rule of law and sound economic policies. 


\section{References}

Boone, Peter. 1994. "The Impact of Foreign Aid on Savings and Growth" London School of Economics, mimeo:

-1996. "Politics and the Effectiveness of Foreign Aid" European Economic Review 40: 289-329.

Burnside, C. and D. Dollar (1997) "Aid, Policies, and Growth," Policy Research Paper 1777.

Central Intelligence Agency, 1996, The World Factbook. Brassey's.

Frey, B. and F. Schneider (1986) "Competing Models of Intemational Lending Activities" Journal of Development Economics, 225-45

Gastil, RD., 1990, "The Comparison Survey of Freedom," Studies in Comparative Intemational Development 25:1, 25-50.

Gastil, R.D., Freedom in the World: Political Rights and Civil Liberties, 1986-87, Greenwood Press.

Greene, William, 1993, Econometric Analysis, Prentice Hall

Inter-University Consortium for Political and Social Research, 1982, CN Roll Call Data, 1946-1985 [computer file], Ann Arbor, MII.

Jepma, C. (1997) "On the Effectiveness of Development Aid" World Bank, unpublished.

Lumsdaine, D.H. (1997) Moral Vision in International Politics, Princeton University Press. Princeton, NJ.

McKinley, R.D. and R. Little (1978) "The Erench Aid Relationship" Development and Change, 459-78. 
McKinlay, R. D., and R. Litle 1979. "The U.S. Aid Relationship: A Test of the Recipient Need and Donor Interest Models." Political Studies 27 (2): 236-250.

Maizels, A and M. Nissanke (1984) "Motivations for Aid to Developing Countries" Frorld Development, $879-900$.

OECD, 1996, Geographicat Distribution of Financial Flows to Aid Recipients: 1960-95 (CD-Rom).

Political Risk Services, International comny Risk Guide data.

Sachs, Jeffey D. and Andrew Wamer. 1995. "Economic Refom and the Process of Global Integration." Brookings Papers on Economic Activity (1):1-118.

Schraeder, P. S. Fook and B. Taylor (1998) "Clarifying the Foreign Aid Puzzle: A Comparison of American Japanese, French and Swedish Aid Fow" World Politics, 294-320.

Summers, R, and A. Heston, 1988, A New Set of Intemational Comparisons of Real Products and Price Levels Estimates for 130 Countries, 1950-1985, Review of Income and Wealth, 34, 1-25 (updated to 1992).

Trumbull, W. and H. Wall (1994) "Estimating Aid-Allocation Criteria with Panel Data" The Economic Joumal, $876-92$

Worid Bank, World Debt Tables, various years, Johns Hopkins U. Press. 
Table 3.1. Correlation of Aid Per Capita and Other Variables

\begin{tabular}{|c|c|c|c|c|c|c|}
\hline & Openness & Democracy & Colony & DFI & $\begin{array}{c}\text { Initial } \\
\text { locome }\end{array}$ & Population \\
\hline Aid per capita & .13 & .18 & .21 & .06 & .12 & -.34 \\
\hline Openness & & .32 & -.04 & .30 & 31 & -13 \\
\hline Democracy & & & -.24 & .19 & .52 & .09 \\
\hline Colonial Past & & & & .02 & -39 & -.28 \\
\hline DFI & & & & & .27 & -.23 \\
\hline Initial income & & & & & & -.10 \\
\hline
\end{tabular}


Table 3.2. Bilateral Aid to Former Colonies. 1970-94

Donor

Australia

Belgium

France

Germany

Italy

Japan

Netherlands

New Zealand

Portugal

Spain

U.K.

USA

TOTAI
Colony Share (Percent)

55.5

53.7

57.0

2.6

9.0

6.3

17.1

22.5

99.6

4.8

78.0

2.9

19.6 
Table 3.3. Correlation of UN-Friend Variables for Major Powers

\section{Japan Friend UK Friend French Friend}

US Friend

37

.72

.53

Japan Friend

.77

.72

UK Friend

.93

French Friend 


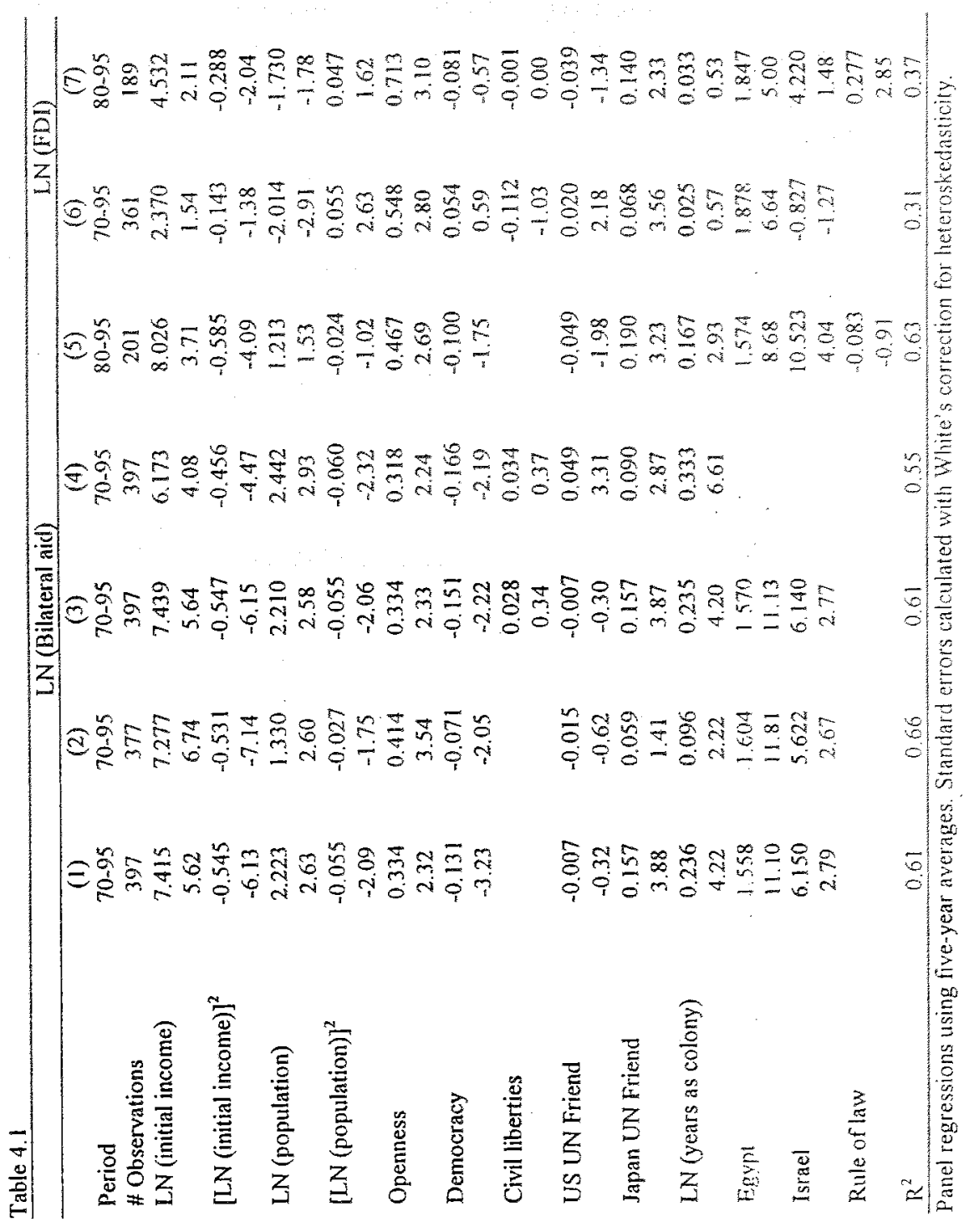




\begin{tabular}{|c|c|c|c|}
\hline $\begin{array}{l}\text { Australia - UN } \\
\text { friend }\end{array}$ & COde & $\begin{array}{l}\text { definition } \\
\text { Percentage of times in which } \\
\text { the recipent has voted in the } \\
\text { UN as AUS }\end{array}$ & $\begin{array}{l}\text { Inter-university Consortium for Political and Social } \\
\text { Research. 1982. and UN (various years). op.cit. }\end{array}$ \\
\hline $\begin{array}{l}\text { Gemany - UN } \\
\text { friend }\end{array}$ & FRDFA & $\begin{array}{l}\text { Percentage of times in which } \\
\text { the recipent has voted in the } \\
\text { UN as DFA }\end{array}$ & $\begin{array}{l}\text { Inter-university Consortium for Political and Social } \\
\text { Research 1982. and UN (various years), op cit. }\end{array}$ \\
\hline $\begin{array}{l}\text { Australiz - own } \\
\text { colony }\end{array}$ & COLSAUS & $\begin{array}{l}\text { Number of years as a Colony } \\
\text { of AuS since } 1900\end{array}$ & $\begin{array}{l}\text { Central Intelligence Agency } 1996 \text {. The World Factbook. } \\
\text { Brassey's Washington. }\end{array}$ \\
\hline $\begin{array}{l}\text { Belgium - own } \\
\text { colony }\end{array}$ & COLSBEL & $\begin{array}{l}\text { Number of years as a Colony } \\
\text { of BEL since } 1900\end{array}$ & Central Intelligence Agency 1996 op cit \\
\hline $\begin{array}{l}\text { France - own } \\
\text { colony }\end{array}$ & COLSFRA & $\begin{array}{l}\text { Number of years as a Colony } \\
\text { of FRA since } 1900\end{array}$ & Central intelligence Agency. 1996 op.cit \\
\hline $\begin{array}{l}\text { Germany - own } \\
\text { colony }\end{array}$ & COLSDFA & $\begin{array}{l}\text { Number of years as a Colony } \\
\text { lof DFA since } 1900\end{array}$ & Centra! Intelligence Agency. 1996. op cit \\
\hline $\begin{array}{l}\text { taly - awn } \\
\text { colony }\end{array}$ & COLSITA & $\begin{array}{l}\text { Number of years as a Colony } \\
\text { of ITA since } 1900\end{array}$ & Centrai intelltigence Agency 1996. \\
\hline $\begin{array}{l}\text { Japan- own } \\
\text { colony }\end{array}$ & COLSJPN & $\begin{array}{l}\text { Number of years as a Colony } \\
\text { of JPN since } 1900\end{array}$ & Central Intelligence Agency. 1996. op.cit \\
\hline $\begin{array}{l}\text { Dutch - own: } \\
\text { colony }\end{array}$ & COLSNLO & $\begin{array}{l}\text { Number of years as a Colony } \\
\text { of NLD since } 1900\end{array}$ & Central Intelligence Agency. 1996 . op cit \\
\hline $\begin{array}{l}\text { Portugal - ow } \\
\text { colony }\end{array}$ & COLSPRT & $\begin{array}{l}\text { Number of yearsas a Colony } \\
\text { of PRT since } 1900\end{array}$ & Central Intelligence Agency. 1996. op.cit \\
\hline $\begin{array}{l}\text { UK-own } \\
\text { colony }\end{array}$ & COLSGBR & $\begin{array}{l}\text { Number of years as a Colony } \\
\text { of GBR since } 1900\end{array}$ & Central inteflligence Agency 1996. op cit \\
\hline $\begin{array}{l}\text { US - own } \\
\text { colony }\end{array}$ & COLSUSA. & $\begin{array}{l}\text { Number of years as a Colony } \\
\text { of USA since } 1900\end{array}$ & Central intelligence Agency 1996 op cit \\
\hline $\begin{array}{l}\text { Years as } \\
\text { Colony }\end{array}$ & COLS & $\begin{array}{l}\text { Number of years as colony of } \\
\text { any colonizer since } 1900\end{array}$ & Central Intelligence Agency 1996. op.cit \\
\hline Aid per capita & ODAPC & $\begin{array}{l}\text { OECD's ODA net per capita: } \\
\text { (constant 85\$) }\end{array}$ & OECD. 1996 op.cit \\
\hline $\begin{array}{l}\text { Colony NOT of } \\
\text { Australia }\end{array}$ & COLNAUS & $\begin{array}{l}\text { Number of years NOT a } \\
\text { Colony of AUS since } 1900\end{array}$ & Central Inteilligence Agency. 1996. op.cit \\
\hline $\begin{array}{l}\text { Colony NOT of } \\
\text { Belgium }\end{array}$ & COLNBEL & $\begin{array}{l}\text { Number of years NOT } a \\
\text { Colony of BEL since } 1900\end{array}$ & Central Intelligence Agency 1996 op cit \\
\hline $\begin{array}{l}\text { Colony NOT of } \\
\text { France }\end{array}$ & COLNFRA & $\begin{array}{l}\text { Number of years NOT a } \\
\text { Colony of FRA since } 1900\end{array}$ & Central Intelligence Agency. 1996 . op cit \\
\hline $\begin{array}{l}\text { Colony NOT of } \\
\text { Germany }\end{array}$ & COLNDFA & $\begin{array}{l}\text { Number of years NOT a } \\
\text { Colony of DFA since } 1900\end{array}$ & Central intelligence Agency. 1996 op cit \\
\hline $\begin{array}{l}\text { Colony NOT of } \\
\text { haly }\end{array}$ & COLNITA & $\begin{array}{l}\text { Number of years NOT a } \\
\text { Colony of ITA since } 1900\end{array}$ & Central Intelligence Agency. 1996, op cit \\
\hline $\begin{array}{l}\text { Colony NOT of } \\
\text { Japan }\end{array}$ & COLNJPN & $\begin{array}{l}\text { Number of years NOT a } \\
\text { Colony of JPN since } 1900\end{array}$ & Central Intelthigence Agency 1996 op cit \\
\hline $\begin{array}{l}\text { Colony NOT of } \\
\text { the Netherlands }\end{array}$ & COLNNLD & $\begin{array}{l}\text { Number of years NOT a } \\
\text { Colony of NLD since } 1900\end{array}$ & Central Inteflligence Agency. 1996 op cit \\
\hline $\begin{array}{l}\text { Colony NOT of } \\
\text { Portugal }\end{array}$ & COLNPRT & $\begin{array}{l}\text { Number of years NOT a } \\
\text { Colony of PRT since } 1900\end{array}$ & Central Intelligence Agency 1996 op cit \\
\hline $\begin{array}{l}\text { Colony NOT of } \\
\text { UK. }\end{array}$ & COLNGBR & $\begin{array}{l}\text { Number of years NOT a } \\
\text { Colony of GBR since } 1900\end{array}$ & Central Intefligence Agency. 1996. op.cit \\
\hline $\begin{array}{l}\text { Colony NOT of } \\
\text { US }\end{array}$ & COLNUSA & $\begin{array}{l}\text { Number of years NOT a } \\
\text { Colony of USA since } 1900\end{array}$ & Central Intelligence Agency. 1996. op.cit \\
\hline
\end{tabular}




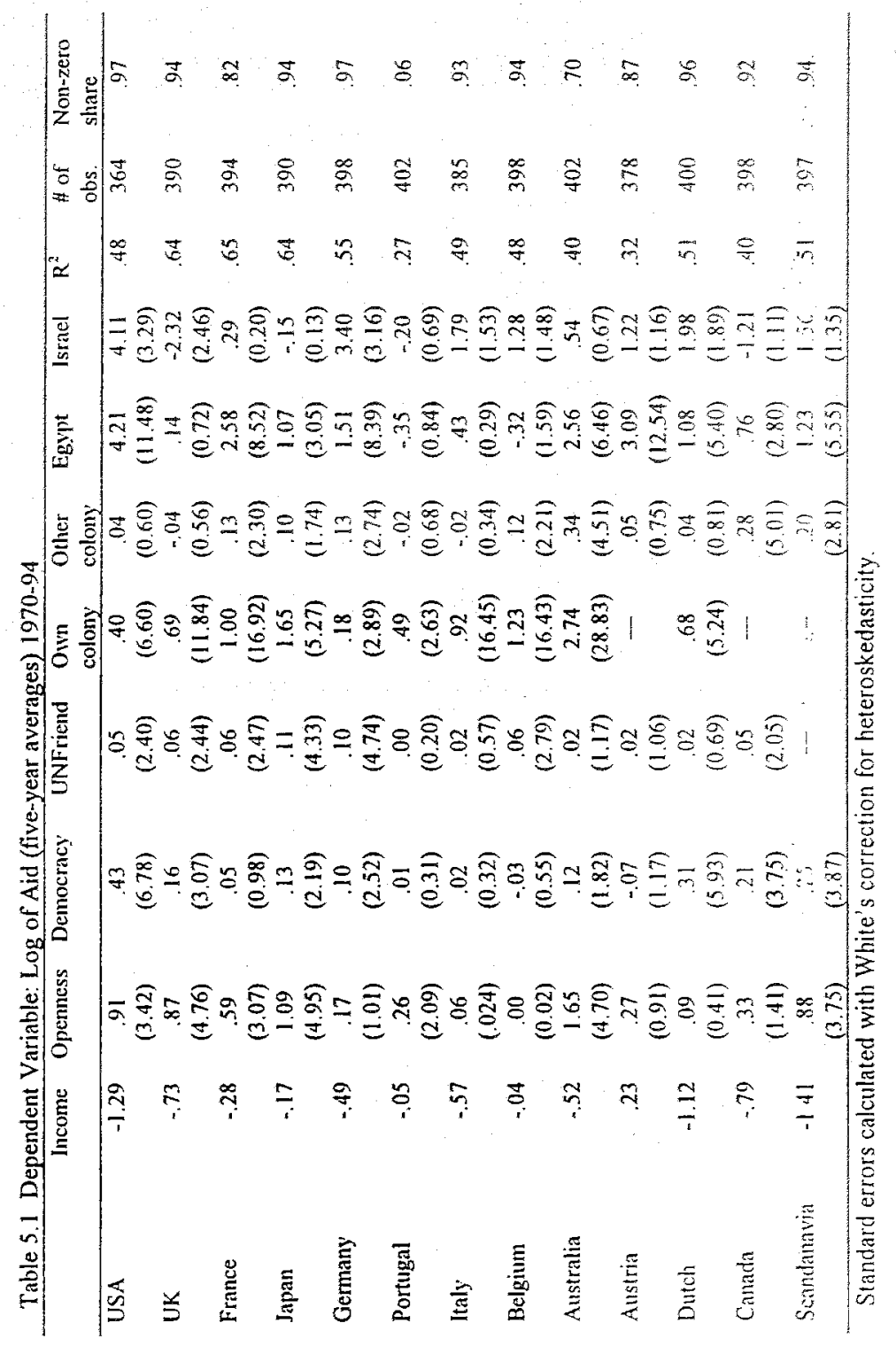




\section{Move to a democratic regime}

\begin{tabular}{|c|c|c|c|}
\hline & Before & During & After \\
\hline ALB & 1.64 & 50.03 & 17.00 \\
\hline$A R G$ & & 0.66 & 0.42 \\
\hline ARG3 & 0.36 & 0.93 & 2.23 \\
\hline BEN & 21.68 & 25.02 & 22.48 \\
\hline BFA2 & 13.86 & 18.93 & 17.94 \\
\hline BGD3 & 8.70 & 9.30 & 6.93 \\
\hline BGDS & 7.51 & 5.41 & 5.03 \\
\hline $\mathrm{BGR}$ & & 3.95 & 5.19 \\
\hline $\mathrm{BOL}$ & 16.65 & 17.45 & 18.54 \\
\hline BOL3 & 17.45 & 18.54 & 27.89 \\
\hline CAF & 26.06 & 26.85 & \\
\hline $\mathrm{CHL} 2$ & 2.68 & 5.88 & 8.09 \\
\hline $\mathrm{COG}$ & & 30.48 & 36.45 \\
\hline COGs & 45.81 & 49.70 & 28.83 \\
\hline CPV & 160.02 & 181.33 & 158.07 \\
\hline CYP2 & 40.14 & 22.15 & 24.34 \\
\hline DOM & 4.37 & 5.87 & 10.41 \\
\hline $\mathrm{DZA}$ & 4.26 & 9.14 & 8.86 \\
\hline$E C U$ & 5.26 & 3.96 & 4.73 \\
\hline FJ2 & 42.92 & 48.76 & 36.60 \\
\hline GAB & 76.81 & 72.12 & 78.93 \\
\hline GHA & 6.24 & 8.06 & 5.95 \\
\hline GHA2 & 7.51 & 6.88 & 6.73 \\
\hline GRD2 & 11.67 & 250.47 & 68.25 \\
\hline GRD3: & 121.30 & 197.42 & 52.95 \\
\hline GUY2 & 32.18 & 26.51 & 20.10 \\
\hline HND & 11.31 & 15.57 & 37.28 \\
\hline HUN: & & 6.64 & 6.16 \\
\hline KHM & 4.85 & 18.51 & \\
\hline KOR & -0.24 & 0.71 & 0.12 \\
\hline KWT2 & 1.89 & 2.73 & 1.95 \\
\hline LSO & & 17.55 & 24.79 \\
\hline LSO2 & 32.43 & 24.45 & \\
\hline$M D G$ & 16.23 & 12.28 & \\
\hline MLI & 27.88 & 20.20 & 21.09 \\
\hline MNG & 0.38 & 15.25 & 34.68 \\
\hline NAM & & 42.81 & 65.40 \\
\hline NER & 25.36 & 21.33 & \\
\hline NGA & 0.71 & 0.19 & 0.24 \\
\hline $\mathrm{NIC}$ & 39.26 & 99.12 & 73.25 \\
\hline NPL & 4.43 & 5.52 & 6.64 \\
\hline NPL2: & 10.48 & 10.73 & 9.66 \\
\hline PAK2 & 3.34 & 4.74 & 5.89 \\
\hline PAN2 & 7.57 & 41.20 & 14.14 \\
\hline
\end{tabular}

\section{Move to an authoritarian regime}

\begin{tabular}{lrrr}
\hline & & & \\
\hline & Before & During & After \\
\cline { 2 - 4 } AFG & & 4.28 & 2.89 \\
ARG2 & 0.66 & 0.42 & 0.84 \\
BFA & 13.30 & 13.38 & 17.71 \\
BFA3 & 17.71 & 18.69 & 15.79 \\
BGD & & 10.29 & 7.46 \\
BGD2 & 8.60 & 8.70 & 9.30 \\
BGD4 & 8.17 & 7.04 & 7.18 \\
BHR & 4.65 & 4.06 & 2.47 \\
BOL2 & 19.04 & 15.34 & 20.81 \\
CHL & & 8.13 & -0.23 \\
COG2 & 36.45 & 32.05 & 26.84 \\
CYP & 12.47 & 25.39 & 62.10 \\
DI & 92.49 & 123.70 & 131.06 \\
DZA2 & 6.55 & 10.01 & 7.56 \\
FI & 38.39 & 45.60 & 47.49 \\
GHA3 & 8.06 & 5.95 & 8.35 \\
GRD & 17.50 & 3.65 & 11.67 \\
GTM & 6.91 & 7.56 & 6.01 \\
GTM2 & 6.01 & 3.96 & 6.42 \\
GUY & & 17.45 & 20.38 \\
HTI & 15.23 & 12.28 & 60.09 \\
KWT & 0.22 & 0.45 & 2.97 \\
KWT3 & 2.03 & 1.62 & 1.10 \\
LBN & 3.42 & 8.04 & 8.03 \\
NGA2 & 0.25 & 0.27 & 1.39 \\
NGA3 & 1.25 & 0.46 & \\
PAK & 7.07 & 5.74 & 3.99 \\
PAN & 16.00 & 14.35 & 14.24 \\
PER2 & 14.76 & 13.87 & 9.82 \\
QAT & 3.30 & 3.36 & 1.87 \\
SDN2 & 18.66 & 13.19 & 5.24 \\
SLE & & 4.53 & 4.79 \\
SUR & 266.98 & 219.84 & 5.68 \\
SWZ & & 36.43 & 53.43 \\
SYC & & 303.52 & 214.09 \\
THA & 2.79 & 3.06 & 5.90 \\
TIK & & 2.88 & 4.91 \\
TON & 161.64 & 192.92 & \\
TUR & 5.43 & 11.25 & 4.11 \\
TUR2 & 7.58 & 2.11 & \\
VEN & 2.18 & 1.12 & 0.98 \\
ZAF & & 0.00 & 0.00 \\
\hline & & & \\
Average & 21.84 & 21.13 & 16.90 \\
\hline & & & \\
\hline
\end{tabular}




\begin{tabular}{lrrr} 
PER & 8.65 & 8.37 & 13.11 \\
PHL & 9.95 & 10.88 & 14.27 \\
POL & & 32.31 & 39.15 \\
PRY & 12.33 & 16.31 & 13.96 \\
SDN & 21.59 & 18.66 & 13.19 \\
STP & 151.62 & 178.31 & 260.72 \\
SUR2 & 6.37 & 47.12 & 98.82 \\
SUR3 & 73.14 & 117.08 & 119.08 \\
SYC2 & 242.32 & 88.21 & \\
THA2 & 3.06 & 5.90 & 6.19 \\
THA3 & 9.58 & 8.35 & 10.26 \\
URY & & 3.79 & 1.15 \\
URY2 & 1.25 & 4.51 & 8.54 \\
WSM & 116.66 & 121.49 & 158.90 \\
ZMB & 38.85 & 54.23 & 35.92 \\
\cline { 2 - 4 } & \multicolumn{3}{|}{} \\
Average & 26.88 & 40.91 & 35.31 \\
\hline
\end{tabular}

'Calculated on balanced panel 
Table 6.2 Ayerage of AIDPC

Move to an open economy

\begin{tabular}{|c|c|c|c|}
\hline & Before & During & After \\
\hline$A R G$ & 3.18 & 5.39 & 3.76 \\
\hline$B E N$ & 16.74 & 24.28 & 23.66 \\
\hline $\mathrm{BOL2}$ & 17.56 & 23.88 & 33.92 \\
\hline $\mathrm{BRA}$ & 1.28 & 0.06 & 0.90 \\
\hline BWA & 71.83 & 82.80 & 73.27 \\
\hline $\mathrm{CHL}$ & 6.25 & 5.30 & -1.97 \\
\hline CMR & 23.19 & 31.76 & 18.88 \\
\hline $\mathrm{COL}$ & 1.39 & 1.40 & 1.60 \\
\hline CRI2 & 58.74 & 71.60 & 52.85 \\
\hline $\mathrm{ECU} 2$ & 12.89 & $12.10^{\circ}$ & 11.66 \\
\hline GHA & 5.68 & 8.06 & 14.35 \\
\hline $\mathrm{GN}$ & 6.37 & 16.82 & 23.93 \\
\hline GMB & 28.70 & 53.24 & $\$ 4.47$ \\
\hline GNB & 32.57 & 45.33 & 57.15 \\
\hline GTM2 & 8.71 & 20.27 & 13.04 \\
\hline GUY & 8.90 & 20.40 & 31.10 \\
\hline HND2 & 40.83 & 40.04 & 27.71 \\
\hline HUN & 0.00 & 3.43 & 7.30 \\
\hline $\mathrm{DN}$ & 6.45 & 11.74 & 8.80 \\
\hline IND & 1.10 & 0.92 & \\
\hline ISR & 225.19 & 399.77 & 235.40 \\
\hline JAM2 & 63.40 & 73.74 & 38.75 \\
\hline JOR & 246.26 & 156.76 & 64.54 \\
\hline KEN2 & 22.17 & 14.12 & 12.53 \\
\hline $\mathrm{KOR}$ & 23.75 & 30.14 & 28.34 \\
\hline LKA & 8.51 & 13.52 & 16.82 \\
\hline LKA3 & 19.80 & 16.60 & 14.93 \\
\hline MAR2 & 9.23 & 11.55 & 13.61 \\
\hline $\mathrm{MEX}$ & 1.55 & 2.17 & 1.25 \\
\hline MLI & 30.14 & 27.68 & 24.59 \\
\hline MRT & 53.37 & 52.90 & 43.43 \\
\hline $\mathrm{NIC2}$ & 39.26 & 99.12 & 73.25 \\
\hline NPL & 10.44 & 10.65 & 9.74 \\
\hline PER2 & 10.73 & 15.57 & 12.81 \\
\hline PHL & 9.95 & 10.88 & 14.27 \\
\hline POL & 0.00 & 23.21 & 26.36 \\
\hline PRY & 10.50 & 13.16 & 16.78 \\
\hline SLV2 & 66.75 & 57.12 & 40.70 \\
\hline TUN & 19.63 & 21.40 & 21.22 \\
\hline TUR & 4.53 & 5.27 & 6.11 \\
\hline TWN & 37.24 & 21.08 & 13.26 \\
\hline UGA & 3.83 & 8.05 & 11.94 \\
\hline URY & 6.60 & 8.98 & $20.0 z$ \\
\hline VEN & 0.90 & 2.22 & 1.15 \\
\hline ZAF & 0.00 & 0.00 & 4.54 \\
\hline $\mathrm{ZMB}$ & 41.78 & 48.89 & 34.06 \\
\hline Average ${ }^{1}$ & 29.26 & 36.05 & 27.93 \\
\hline
\end{tabular}

Move to an closed economy

\begin{tabular}{lrrr}
\hline & & & \\
\cline { 2 - 4 } MAR & Before & Duriag & After \\
\cline { 2 - 4 } BOL & 24.67 & 26.59 & 18.66 \\
CRI & 13.12 & 19.13 & 17.56 \\
ECU & 11.35 & 20.50 & 27.14 \\
GTM & 3.96 & 4.73 & 11.04 \\
HND & 14.13 & 9.66 & 8.47 \\
JAM & 9.06 & 9.16 & 12.90 \\
KEN & 20.64 & 17.85 & 13.68 \\
LKA2 & 20.76 & 12.23 & 13.90 \\
NIC & 16.82 & 19.93 & 20.67 \\
PER & 11.02 & 9.31 & 7.82 \\
SLV & 1.37 & 10.84 & 15.41 \\
SYR & 7.23 & -0.31 & 0.53 \\
VEN2 & 2.18 & 1.12 & 0.98 \\
\hline & & & \\
Average & 12.02 & 12.37 & 12.98 \\
\hline
\end{tabular}

Calculated on balanced panel

bef_zfter $x$ ds 
Table 6.3 Annual Data with Fixed Effects, 77 Countries, $1970-94$ 1855 observations

Dependent variable: Log of Aid per capita

$\begin{array}{lc}\text { Democracy } & -.07 \\ & (3.37) \\ \text { Openness } & -.31 \\ & (2.22) \\ \text { Interaction } & .03 \\ & (0.87) \\ \mathrm{R}^{2} & .70\end{array}$




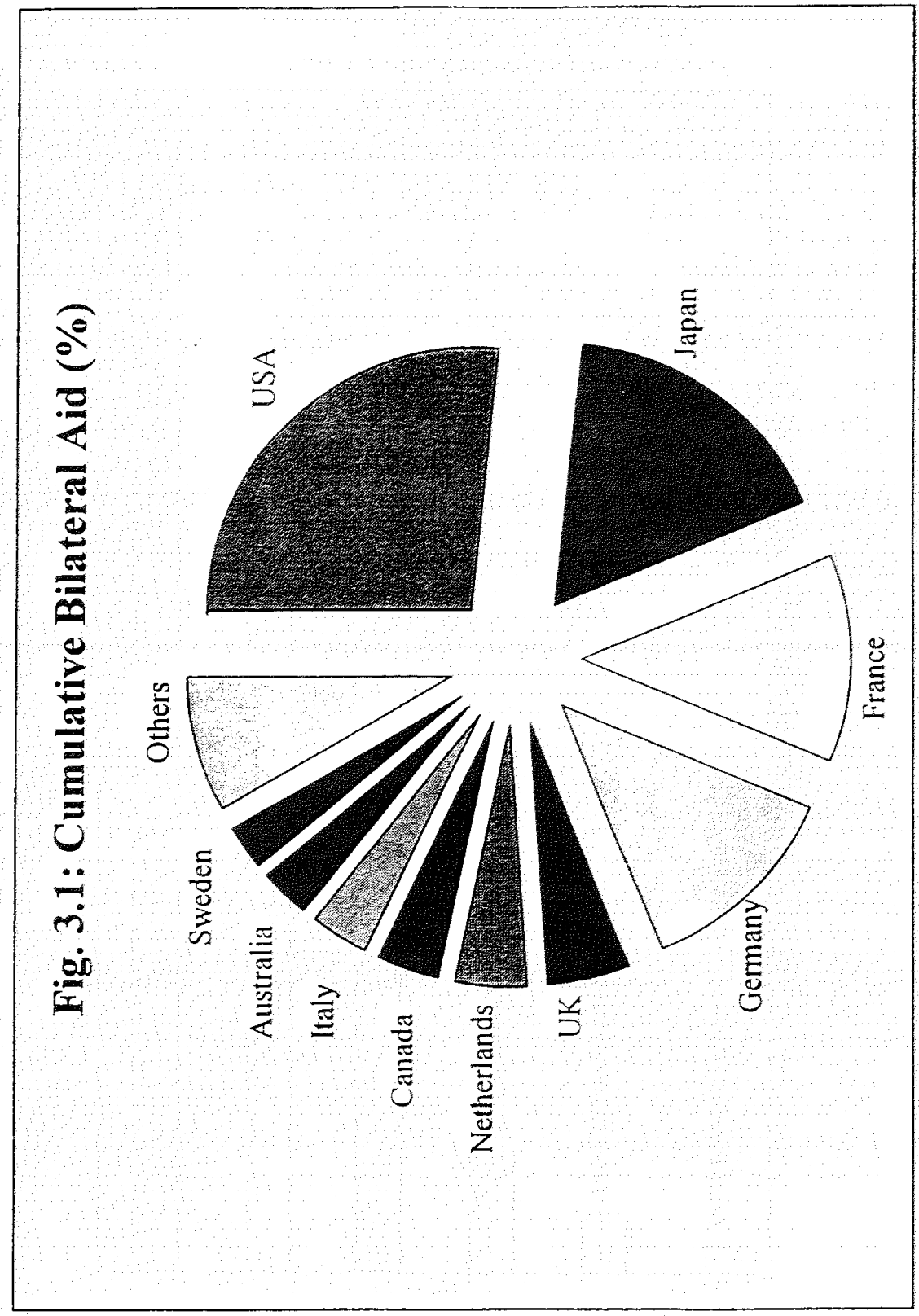




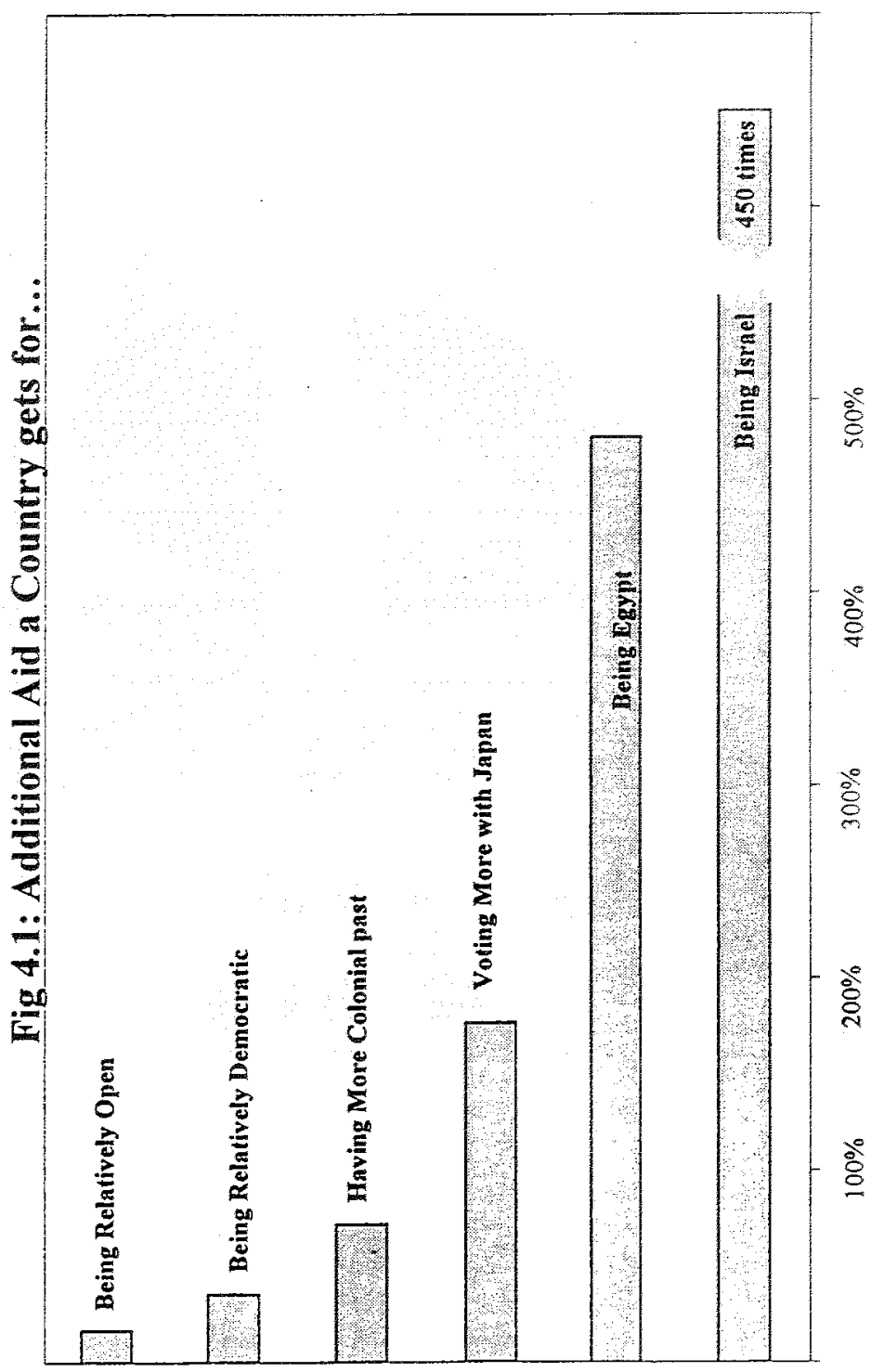




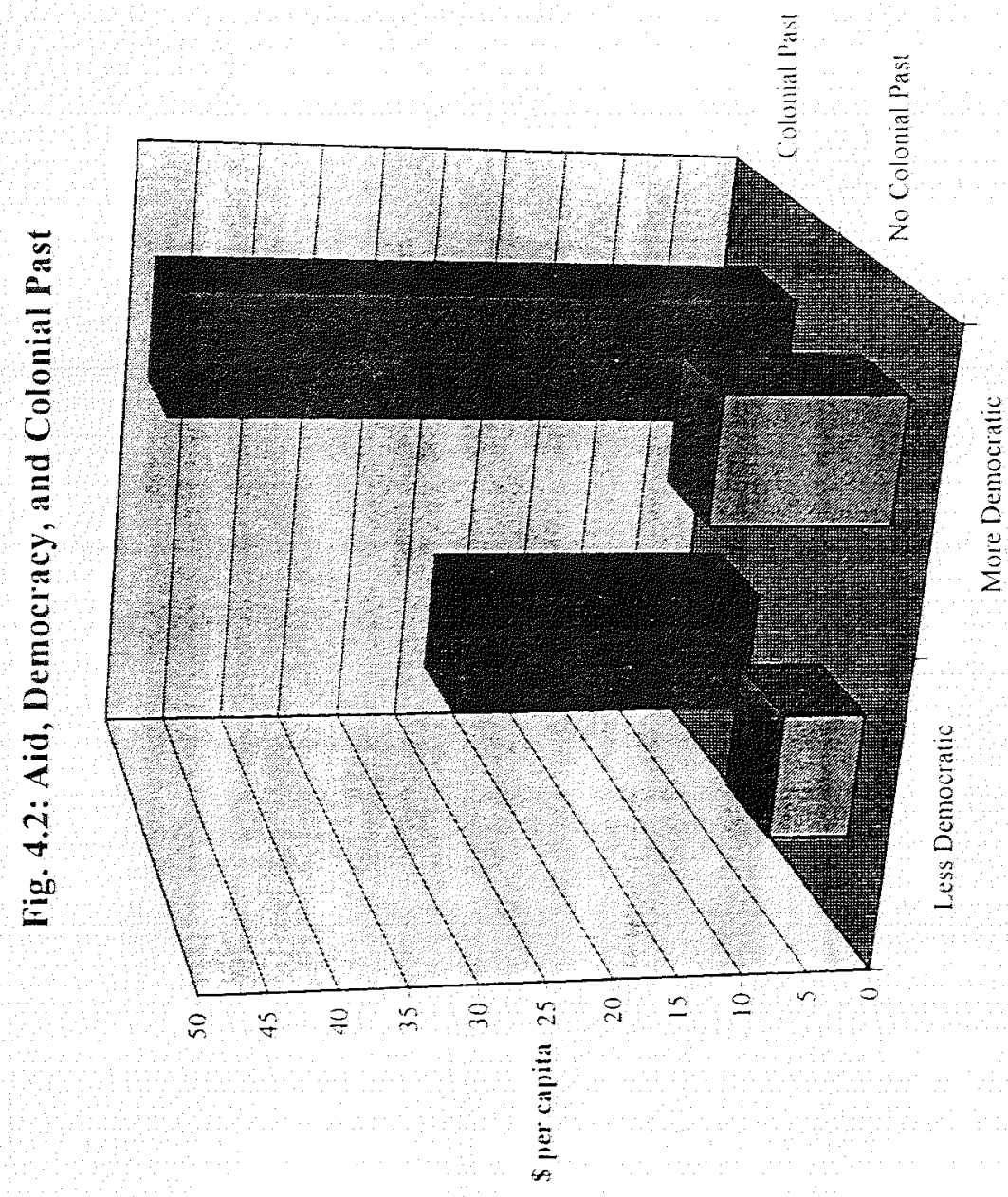




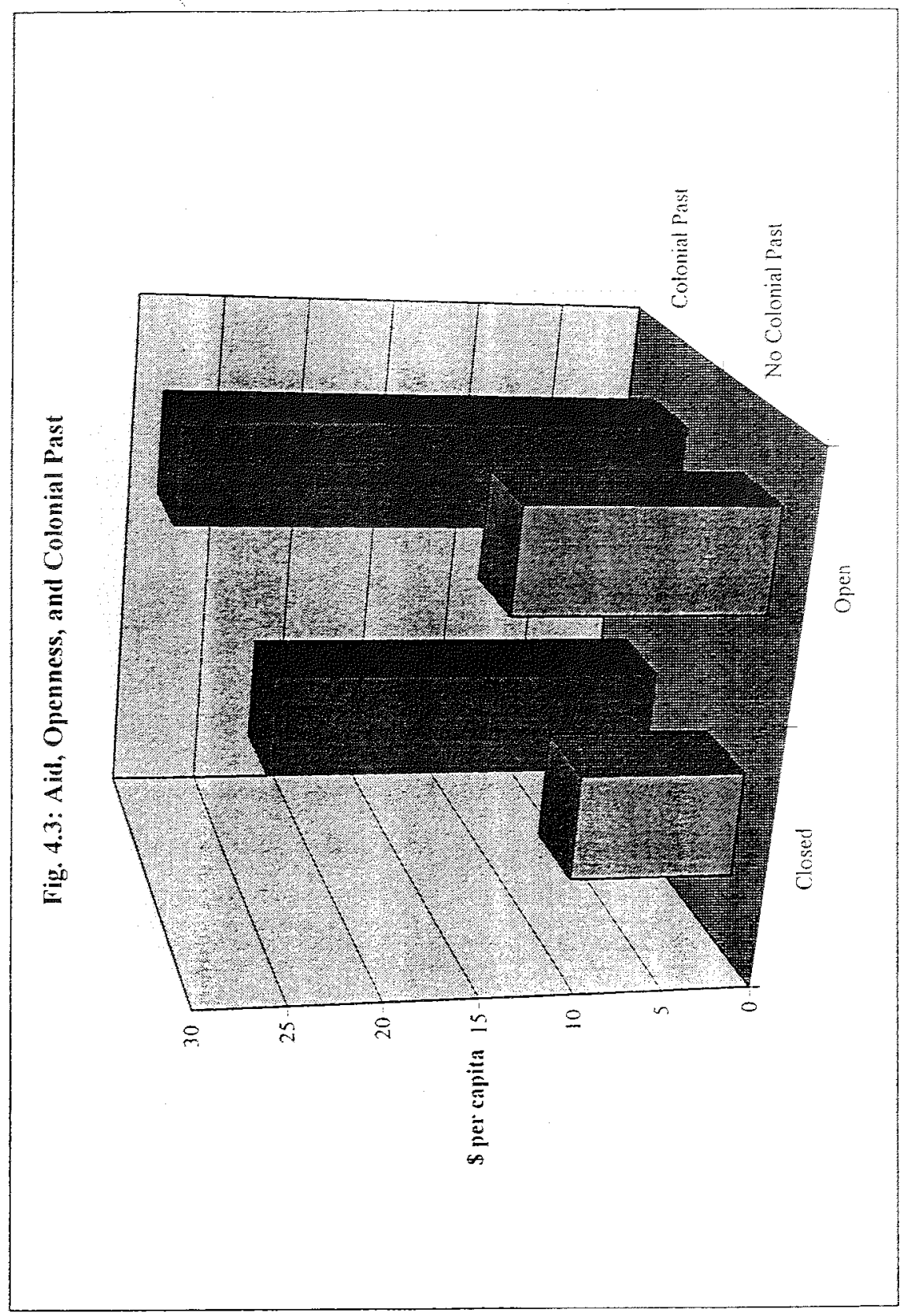




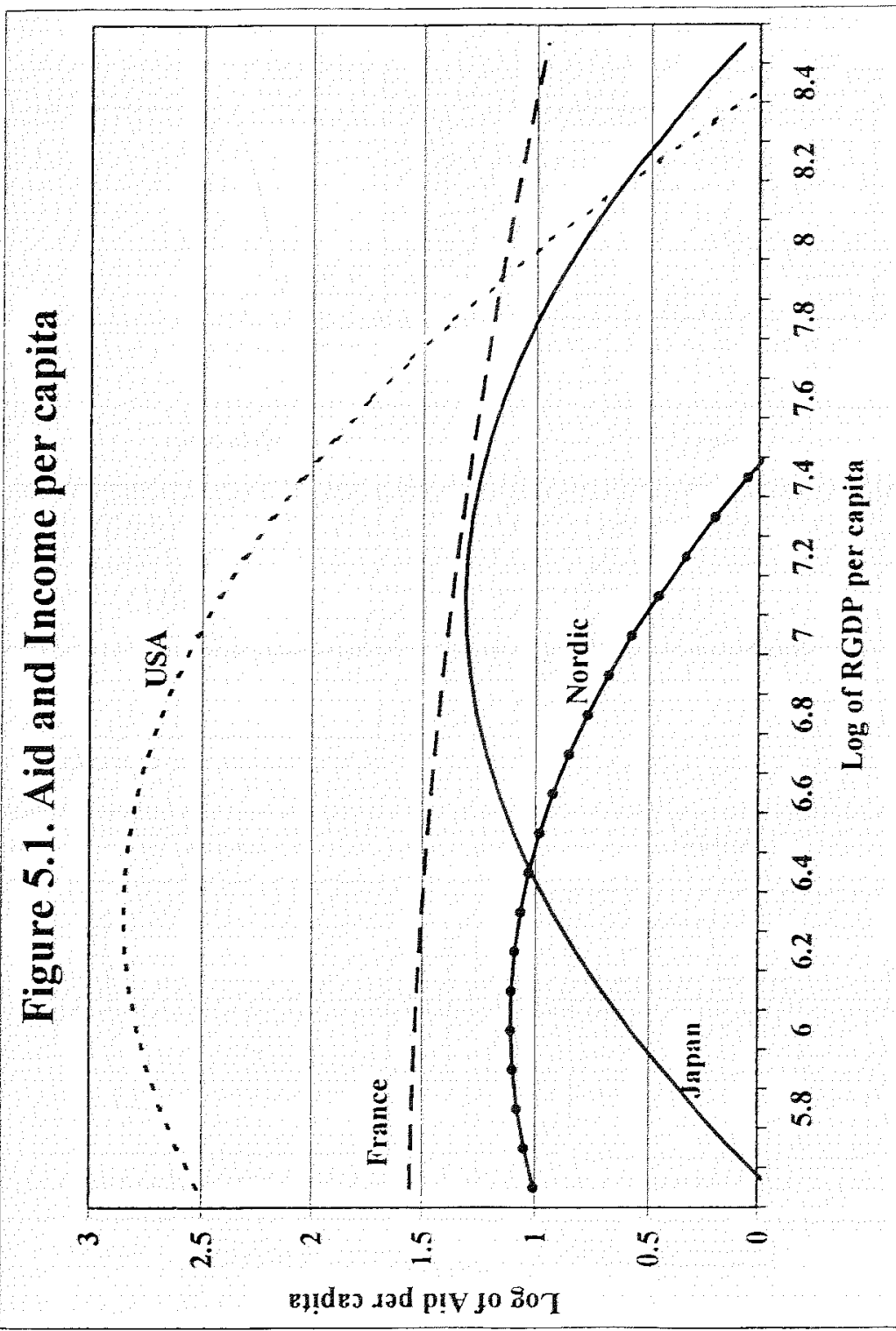


Figure 6.1 Aid and Democracy

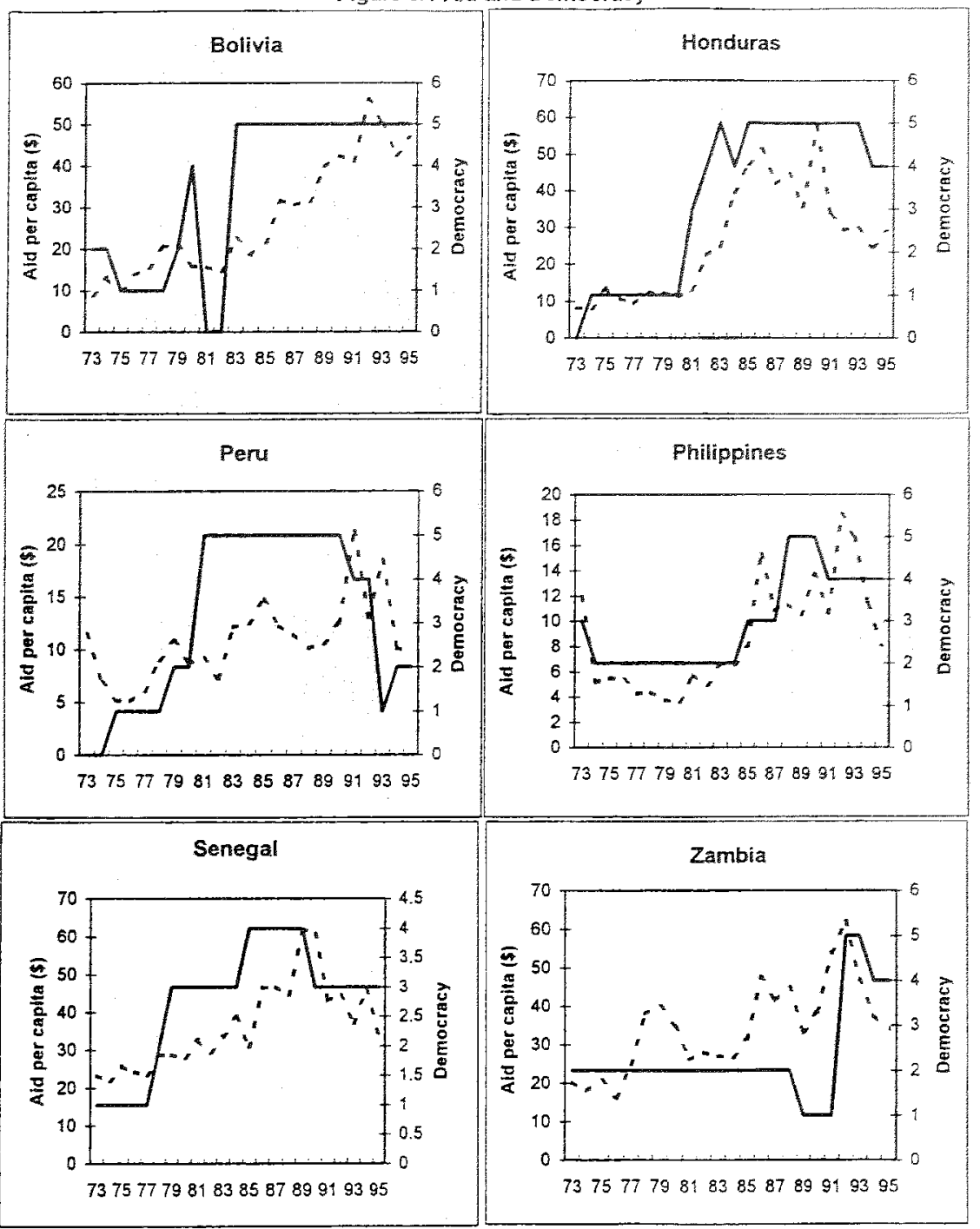

…...... Aid per capita Democracy 
Data Appendix

\begin{tabular}{|c|c|c|c|}
\hline Variable & code & definition & source \\
\hline Openness & OPEN & $\begin{array}{l}\text { Proportion of years in which } \\
\text { the country is open }\end{array}$ & $\begin{array}{l}\text { Sachs, Jeffrey, and Andrew Wamer. 1995: "Economic } \\
\text { Refonm and the Process of Global Integration." Brookings } \\
\text { Papers on Economic Activity } 1: 1-118 .\end{array}$ \\
\hline FDl: & FDI & $\begin{array}{l}\text { Net inflows of FDI (\% gdp); } \\
5 y \text { raverage }\end{array}$ & $\begin{array}{l}\text { Workd Bank. (various years): World Debt Tables Johns } \\
\text { Hopkins Univ. Press. Battimore. }\end{array}$ \\
\hline Rule of Law & LAW & Rule of law: & $\begin{array}{l}\text { Political Risk Services; yarious years Intemational } \\
\text { Country Risk Guide data. Syracuse, NY }\end{array}$ \\
\hline $\begin{array}{l}\text { Democracy } \\
\text { index }\end{array}$ & GASPOL & Folitical Rights & $\begin{array}{l}\text { Gastil, R.D. } 1990 \text {. The Comparison Survey of Freedom: } \\
\text { Experiences and Suggestions" Studies in Comparative } \\
\text { Int"l Develop. } 25 \text { (1): 25-50: Gasti! R.D. 1987. Freedom in } \\
\text { the Word: Political Rights and Civil Liberties 1986-1987. } \\
\text { Greenwood Press, Westport, CT }\end{array}$ \\
\hline $\begin{array}{l}\text { Civil Liberties } \\
\text { index }\end{array}$ & GASCIV & Civil Liberties & Gastil, R.D. 1990 op.cit \\
\hline Australia-Aid & ODAAUS & $\begin{array}{l}\text { Australia's ODA net (mill. } \\
\text { constant } 85 \$ \text { ) }\end{array}$ & $\begin{array}{l}\text { OECD. 1996. Geographical Distribution of Financial Flows } \\
\text { to Aid Recipients: 1960-95. Faris (CD-Rom) }\end{array}$ \\
\hline Austria-Aid & ODAAUT & $\begin{array}{l}\text { Austria's ODA net (mill. } \\
\text { constant } 855 \text { ) }\end{array}$ & OECD. 1996. op.cit \\
\hline Belgium - Aid & ODABEL & $\begin{array}{l}\text { Beigium's ODA net (milt: } \\
\text { constant } 855 \text { ) }\end{array}$ & OECD. 1996. Op.cit \\
\hline Canada - Aid & ODACAN & $\begin{array}{l}\text { Canada's ODA net (mill: } \\
\text { constant } 85 \$ \text { ) }\end{array}$ & OECD 1996 op cit \\
\hline Denmark-Aid & ODAONK & $\begin{array}{l}\text { Denmark's ODA net (mill. } \\
\text { constant } 855 \text { ) }\end{array}$ & OECD 1996 op.cit \\
\hline Finiand - Aid & ODAFIN & $\begin{array}{l}\text { Finland's ODA net (mill. } \\
\text { constant } 85 \$ \text { ) }\end{array}$ & OECD 1996 op cit \\
\hline France-Aid & ODAFRA & $\begin{array}{l}\text { France's ODA net (mill: } \\
\text { constant } 855 \text { ) }\end{array}$ & OECD. 1996. Op.cit \\
\hline Germany - Aid & ODADEU & $\begin{array}{l}\text { Germany's ODA net (mill: } \\
\text { constant } 855 \text { ) }\end{array}$ & OECD. $1996.0 \mathrm{p} . \mathrm{Cit}$ \\
\hline Ireland - Aid & ODAIRL & $\begin{array}{l}\text { ireland's ODA net (mill. } \\
\text { constant } 85 \$ \text { ) }\end{array}$ & OECD.1996. op.cit \\
\hline Italy-Aid & ODAITA & $\begin{array}{l}\text { Italy's ODA net (mill constant } \\
85 \$ \text { ) }\end{array}$ & OECD. $1996.0 p$.cit \\
\hline Japan - Aid & ODAJPN & $\begin{array}{l}\text { Japan's ODA net (mill } \\
\text { constant } 85 \$ \text { ) }\end{array}$ & OECD. 1996. op cit \\
\hline Luxembourg:- & ODALUX & $\begin{array}{l}\text { Luxembourg's ODA net (mil!. } \\
\text { constant } 859 \text { ) }\end{array}$ & OECD. 1996. Op.cit \\
\hline $\begin{array}{l}\text { Netherlands - } \\
\text { Aid }\end{array}$ & ODANLD & $\begin{array}{l}\text { Nethertands' ODA net (mill: } \\
\text { constant } 85 \$ \text { ) }\end{array}$ & OECD. 1996. Op.cit \\
\hline $\begin{array}{l}\text { New Zealand - } \\
\text { Aid }\end{array}$ & ODANZL & $\begin{array}{l}\text { New Zealand's ODA net (mill. } \\
\text { constant } 855 \text { ) }\end{array}$ & OECD $1996.00 . \mathrm{cit}$ \\
\hline Nowway - Aid & ODANOR & $\begin{array}{l}\text { Norway's ODA net (mill } \\
\text { constant } 855 \text { ) }\end{array}$ & OECD 1996 op cit \\
\hline Portugal - Aid & ODAPRT: & $\begin{array}{l}\text { Portugal's OOA net (mill } \\
\text { constant } 85 \$ \text { ) }\end{array}$ & OECD 1996 op cit \\
\hline Spain - Aid & ODAESP & $\begin{array}{l}\text { Spain's ODA net (mill. } \\
\text { constant } 855 \text { ) }\end{array}$ & OECD. 1996, op cit \\
\hline Sweden - Aid & ODASWE & $\begin{array}{l}\text { Sweden's ODA net (mill. } \\
\text { constant B5S) }\end{array}$ & TOECD 1996. op cit \\
\hline
\end{tabular}


Codes for Recipient Countries

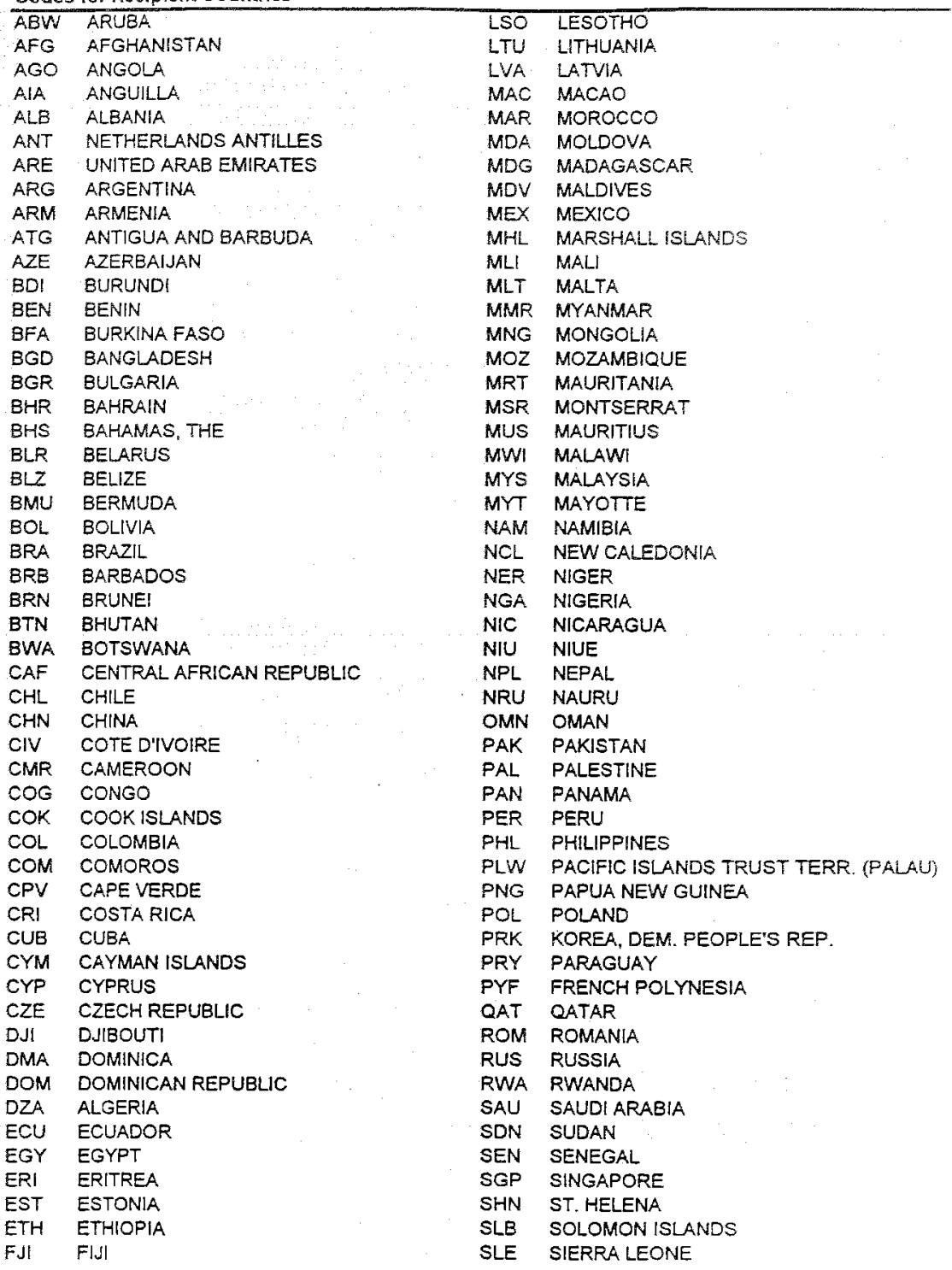


Codes for Recipient Countries

\begin{tabular}{|c|c|c|c|}
\hline FLK & FALKLAND ISLANDS & SLV & EL SALVADOR \\
\hline FSM & MICRONESIA & SOM & SOMALIA \\
\hline GAB & GABON & STP : & SAO TOME AND PRINCIPE \\
\hline GEO & GEORGIA & SUR & SURINAME \\
\hline GHA & GHANA & SVK & SLOVAK REPUBLIC \\
\hline GIB & GIBRALTAR & SWZ & SWAZILAND \\
\hline $\mathbf{G I N}$ & GUINEA & SYC & SEYCHELLES \\
\hline GMB & GAMBIA, THE & SYR & SYRIAN ARAB REPUBLIC \\
\hline GNB & GUINEA-BISSAU & TCA & TURKS AND CAICOS ISLANDS \\
\hline GNQ & EQUATORIAL GUINEA. & TCD & $\mathrm{CHAD}$ \\
\hline GRD & GRENADA & TGO & TOGO \\
\hline GTM & GUATEMALA: & THA & THAILAND \\
\hline GUY & GUYANA & TJK & TANIKISTAN \\
\hline HKG & HONG KONG & TKL & TOKELAU: \\
\hline HND & HONDURAS & TKM & TURKMENISTAN \\
\hline HTI & HA.TT & TON & TONGA \\
\hline HUN & HUNGARY & no & TRINIDAD AND TOBAGO \\
\hline IDN & INDONESIA & TUN & TUNISIA \\
\hline IND & INDIA & TUR & TURKEY \\
\hline IRN & IRAN, ISLAMIC REPUBLIC OF & TUV & TUVALU \\
\hline IRQ & IRAQ & TWN & TAIWAN, CHINA \\
\hline ISR & ISRAEL & $T Z A$ & TANZANIA \\
\hline JAM & JAMAICA & UGA & UGANDA: \\
\hline JOR & JORDAN & UKR & UKRAINE \\
\hline KAZ & KAZAKHSTAN & URY & URUGUAY \\
\hline KEN & KENYA & UZB & UZBEKISTAN \\
\hline$K G Z$ & KYRGYZ REPUBLIC & VCT & ST VINCENT AND THE GRENADINES \\
\hline $\mathrm{KHM}$ & CAMBODIA & VEN & VENEZUELA \\
\hline KIR & KIRIBATI & VGB & BRITISH VIRGIN ISLANDS \\
\hline KNA & ST. KITTS AND NEVIS & VNM & VIET NAM \\
\hline KOR & KOREA, REPUBLIC OF & VUT & VANUATU \\
\hline KWT & KUWAIT & WLF & WALLIS AND FUTUNA \\
\hline LAO & LAO PEOPLE'S DEMOCRATIC REP. & WSM & WESTERN SAMOA : \\
\hline LBN & LEBANON & YEM & YEMEN, REPUBLIC OF \\
\hline LBR. & LIBERIA: & ZAF & SOUTH AFRICA \\
\hline LBY & LIBYA & ZAR & ZAIRE \\
\hline LCA & ST. LUCIA & $\mathrm{ZMB}$ & ZAMBIA \\
\hline LKA & SRI LANKA & ZWE & ZIMEABWE \\
\hline \multicolumn{4}{|c|}{ Codes for Donor Countries } \\
\hline AUS: & AUSTRALIA & JPN & JAPAN \\
\hline AUT & AUSTRIA & LUX & LUXEMBOURG \\
\hline BEL & BELGIUM & NLD & NETHERLANDS \\
\hline CAN & CANADA & NZL & NEW ZEALAND \\
\hline DNK & DENMARK & NOR: & NORWAY \\
\hline FIN & FINLAND. & PRT & PORTUGAL \\
\hline FRA & FRANCE & ESP. & SPAIN \\
\hline DEU or & DFA GERMANY & SWE & SWEDEN \\
\hline IRL & IRELAND & CHE & SWITZERLAND \\
\hline ITA & ITALY: & GBR & UNITED KINGDOM \\
\hline & & USA & UNITED STATES \\
\hline
\end{tabular}

